\title{
LINGUISTIC HYBRIDITY AND DEVELOPMENTAL PERSPECTIVES IN CAMEROON
}

\author{
Charles Esambe Alobwede 1 (1) \\ ${ }^{1}$ Department Of English, University Of Yaounde, Cameroon
}
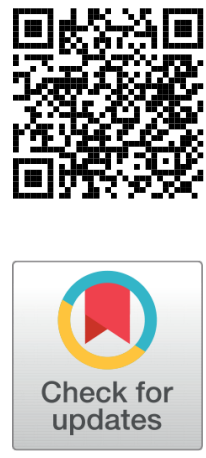

Received 1 April 2021

Accepted 16 April 2021

Published 30 April 2021

Corresponding Author

Charles Esambe Alobwede, calobs

@yahoo.com

DOI $10.29121 /$

granthaalayah.v9.i4.2021.3852

Funding: This research received no specific grant from any funding agency in the public, commercial, or not-for-profit sectors.

Copyright: (C) 2021 The Author(s). This is an open access article distributed under the terms of the Creative Commons Attribution License, which permits unrestricted use, distribution, and reproduction in any medium, provided the original author and source are credited.

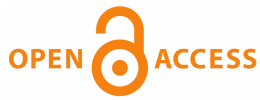

\section{ABSTRACT}

Language politics and the issue of official bilingualism have been factors in Cameroonian politics since the country obtained independence from its respective colonial masters. These sociolinguistic phenomena have impacted not only on the operation of state institutions, but also on the cultural and linguistic make-up of the society. This has given birth to cultural and linguistic hybridity and perspectives in development. French and English, the two official languages of the country and a legacy of colonialism have created linguistic and sometimes political, social and cultural barriers. Bilingualism, a policy adopted by the government of Cameroon to achieve national unity and integration has often been criticized because of some of its shortcomings. However, this article seeks to prove that despite such shortcomings, cultural hybridity and bilingualism have positively impacted the political, historical, economic, social and cultural factors of development in Cameroon.

Keywords: Official Bilingualism, State Institutions, Language Policy, Official Languages, Culture, Linguistic Hybridity

\section{INTRODUCTION}

The impact of colonialism as a historical and sociolinguistic phenomenon is still felt in multilingual societies within the African continent and beyond. It shapes and models people's identities, ideologies, perceptions, attitudes, and cultures. In postcolonial settings, certain attitudes, languages and cultures bring about competition and linguistic/cultural development which open doors for citizens to confront existing advancements in economy and technology, although some linguists like Ngefac (2011) and Anchimbe and A (2011) think that these attitudinal tendencies bring about conflicts and unhealthy competitions, especially when people in a multilingual setting resort to defining their identities with a particular colonial language.

Among the countries of the world where the phenomenon of multilingualism is experienced, Cameroon could be seen as one of the most fascinating. Irrespective 
of the perspective from which one may look at official bilingualism in the country, it is a complicated issue to handle. The country's colonial past gave birth to official bilingualism where two languages - French and English - are used simultaneously in official milieus. Furthermore, the existing plurality of ethnic languages and customs has brought about hybrid cultures in which there is a mélange of values of the different existing cultures in the country.

The term hybrid or hybridity is both a linguistic and a postcolonial literary concept that served certain interests which were central to the colonial enterprise Anjali (2007). Hybridity as claimed by some theorists in postcolonial studies can lead out of various constraints in conceiving agency. The concept can thus be considered a 'racial term'. The present article defines the concept as the merging of two or more distinct systems into a single unit. In Cameroon, hybridity is experienced at different levels: at the level of intermarriages between Cameroonians of different cultural backgrounds; at the linguistic level; at the level of the legal system with the harmonization of the Cameroon Criminal Procedure Code and at the artistic level with artists like Lapiro de Mbanga, Ndedi Eyango, Ateh Bazor, Charlotte Dipanda, Lady Ponce, etc. These artists have been able to create artistic repertoires in which Cameroonian home languages (HL) are merged at times with either the English language or the French language or Pidgin English (PE). The most common hybrid types are French and PE mixtures as in most of Lapiro's songs; HL and PE mixtures as in the songs of Eyango; HL and French as in the songs of Manu Dibango and Lady Pounce. There are equally examples of HL and English mixtures as in the songs of Ateh Bazor.

Added to hybridity is widespread individual bilingualism in the country, that is, the alternate use of two or more languages involving home languages. Such use may be within one language family as in the instance of Bantu and grass-field languages of the Congo-Kordofanian family. It may even extend across two language families as in the example of bilingualism and trilingualism involving languages of the CongoKordofanian languages and the Afro-Asiatic languages Ayafor (2005). But because of the non-official status of these languages, such bilingualism/trilingualism is not recognized by the state.

Ongoing research on bilingualism as a linguistic phenomenon has seen the publication of hundreds of reports. Such research endeavors address the subject from different perspectives. Many of the publications have adopted an interdisciplinary approach to the discussion of the subject Ayafor (2005). It is also common knowledge that most of these publications are a result of many conferences around the globe. Such research and conferences are a result of the upmost importance of a bilingual/trilingual society in the modern world with the advances in technology. Data (2000) quoted in Anchimbe and A (2011) opines that for citizens of a country, literacy in two or more languages is important in developing a deep understanding of their languages and cultures. Such literacy equally plays an important role in giving the citizens choices to develop their cultural identity and academic options. 


\section{THE LINGUISTIC BACKGROUND}

The official languages of Cameroon are French and English and a further 286 homes languages and dialects Ethnologue (2005). Of these, 279 are 'living' languages, three are second languages without mother-tongue speakers and none is spoken as a mother-tongue by more than $4 \%$ of the population Gordon and Raymond (2005). According to a CIA Report (2006), languages in Cameroon can be merged into groupings as follows: Cameroon Highlanders, also called semi Bantu or Grass-Field (which includes languages like Bamileke, Bamoun, Tikar, Northwest Plateau dialects); Equatorial Bantu and Eastern Nigritic made up of Beti-Pahouin and Fang-Pahouin (which include languages like Bulu, Ewondo, Eton, Mfang, Mpangwe); Kirdi or Fula which stands for 'Pagan' (which includes languages like Mandara, Toupouri, Adamawa languages along the Logone River); Fulani (which includes Fulfulde or Pulaar or Peul, Tukulor in Senegal, etc); and Northwestern Bantu or Forest Bantu or Coastal Bantu (which includes Duala, Bass-Bakoko, Akoosé, Bafia, etc). There are other African languages (Shuwa or Choa Arabs, and Chadic which comprises Kanuri and Hausa, the Ejagham or Ekoi, and Pygmies), and Non-African languages (small minority of Europeans of English, French and German backgrounds as well as of Asian, mainly Lebanese expatriates).

The linguistic history of Cameroon can be traced as far back as the slave trade era during which Pidgin English (PE) was born together with Creole English (KE). According to Mbassa (1976) , Pidgin English is the only non-ethnic, non-educated language used in almost every part of Cameroon. Even after independence and reunification in 1960 and 1961, the language remained the most widely single language used in Cameroon, and which links, at least potentially, Cameroonians from different language groups either educated in French or English, or non-educated at all in either of these Received languages (RL).

With the coming of Baptist Missionaries in 1841, there was the introduction of a hybrid education system. Mission schools were opened in Bimbia, Douala and Victoria (present day Limbe) where education was formally organized using the linguistic media, Duala and English. The coming of the missionaries initiated a Home Language (HL) + Received Language (RL) education in the country.

During this period, PE saw its function increase and its spread widen. It became the lingua franca in Cameroon. It was used as a confessional language, a language of trade, and a language of the administration, law and order. But because it was predominantly or almost exclusively a spoken variety, it was greatly marked by orality. As it spread, it became differentiated both regionally and socially, potentially so in its phonology and vocabulary Mbassa (1976). Mbassi Manga (ibid) avers that PE became the mother-tongue of descendants of liberated slaves who settled in Victoria as from 1846. Because of these Cameroonians, a PE variety became a mother-tongue, and was called (as in the West Indies and Sierra Leone) Krio, which is similar to PE, especially the variety spoken in Victoria (Limbe). 
Mbassi Manga writes that in French Cameroon, PE was affected by the French language. More precisely, with time and up to the eve of independence, PE in French Cameroon became so hybridized with French language values that it was labeled Francophone Cameroon PE. Its core, grammatical and lexical structures are English, but in its realization, it is significantly marked by French grammatical forms and especially French lexical items. PE constitutes, for the Republic of Cameroon, a very useful medium of communication between Anglophone and Francophone Cameroonians, and the only non-tribal as yet non-educated lingua franca. Mbassi Manga concludes that ever since Cameroon English became a potential linguistic reality, it has had an unbroken usage in its PE variety for 503 years (1472-1975). This means that by 2021, PE in Cameroon has had an unbroken usage of 549 years (1472-2021).

The coming of the Germans in 1884 was a turning point in the linguistic history of Cameroon, giving that after annexing the country, the German colonialists used the German language to communicate with the local population who were not obliged to learn and 'master' the German language. After the First World War (WW1) which saw the defeat of the Germans by the combined Allied Forces, the League of Nations handed Cameroon to England (about 1/3 of the territory) and to France (about 3/4 of the territory) as trust territories. At the end of the Second World War (WWII), the United Nations Organization reiterated the decision of the League of Nations and left the administration of the Cameroons in the hands of the English and the French, though the territories moved from the status of trust territories to that of mandated territories. This situation lasted till $1^{\text {st }}$ January 1960 when the French-speaking section of the country got its independence. The English-speaking section gained its independence on $1^{\text {st }}$ September 1961 when both sections joined to form the Federal Republic of Cameroon.

After independence, the new government of the Federal Republic had the 'choice' of either starting a new linguistic policy from scratch by adopting home languages (HL) as languages for official communication or to continue with the use of inherited received language (RL), that is, English and French. Adopting the first option would have meant starting from scratch by developing any chosen language and imposing it on every Cameroonian. Giving that the country had just come out of a very serious political crisis with the issue of 'maquisards' ${ }^{1}$, the political authorities thought it wise to continue with the use of English and French as official languages. This was meant to consolidate national unity and integration geared towards development as well as to benefit from bilateral and multilateral cooperations, with the international community.

The idea of 'choice' within a hybrid state is very productive in different contexts. In both Fanon and Glissant, it is connected to the type of dialectic posited between reality and utopia and it is called up at the moment of an ethical decision made to be a 'free' subject, thus evoking the Sartrean concept of both freedom and choice. Such

\footnotetext{
${ }^{1}$ Maquisards were considered as a group of rebels who wanted to overthrow the new government born after independence; although the group members saw themselves as liberation fighters who wanted to free the country from the grip of the colonizers.
} 
estimation calls on individuals to enter into a conscious ethical engagement in their orientation with otherness.

For this reason, the government put emphasis on the official bilingual nature of the country and on the promotion of bilingualism. This status is inscribed in article 1 , paragraph 3 of the different constitutions ${ }^{2}$ of the country as well as in a good number of official discourse and texts enacted by government. Mbangwana (1999) holds that:

“En préferant ainsi le français et l'anglais, les autorités camerounaises ont été sûrement influencées par les mêmes critères ayant motivé le choix des deux langues au lendemain des indépendances : résoudre le problème de plurilinguisme existant dans le pays, préserver l'unité nationale dans une nouvelle fédération encore fragile, continuer la politique coloniale en matière de politique linguistique".

(In adopting French and English, the Cameroonian authorities were influenced by similar criteria as those that motivated the choice of both languages at the eve of independence: to resolve the existing multi-linguistic problem, to preserve national unity within the young and fragile federation, and to continue with the colonial linguistic policy).

National unity and bilingualism became complementary and inseparable as was shown during the National Forum on Education in 1991. During the National Forum on Culture organized in 1995, the need to maintain national unity through bilingualism and biculturalism was further expressed. Conversely, some Cameroonian linguists think that bilingualism is a major socio-political problem in Cameroon Mbangwana (1999), Chumbou (1980), Ejedepang-Koge (1985). This is because since $197^{3}$ bilingualism has hardly been harmonized between the English-speaking and Frenchspeaking parts of the country, giving that the French language has been more utilized as a language of priority over the English language. In spite of this, a number of measures have been taken by government for the harmonization of the bilingual system at different levels of the administrative machinery. As shown below, some measures have been taken at the levels of the administration, the judiciary and the education sector.

Though the government has been hesitant in giving home languages pride of place, recent studies show that these languages, which are carriers of Cameroonian cultures are today recognized as forces to reckon with. Anjali (2007) in quoting the Summer Institute of Linguistics (SIL) 2004 Report, holds that 166 home languages have already been standardized: 36 are being taught in some primary schools; 18 have translated versions of the New Testament and 30 have translated portions of the Scriptures.

The most recent development in linguistic advances in Cameroon is the creation of the Department of Cameroonian languages and cultures at the Yaounde Higher Teacher Training College (ENS) ${ }^{4}$. Ngefac (2011) opines that this is a promising sign

\footnotetext{
${ }^{2}$ Since independence, Cameroon has had four major Constitutions: 1961, 1972, 1984, and 1996.

3 The birth of the United Republic of Cameroon

${ }^{4}$ ENS : French acronym which stands for 'Ecole Normale Supérieure'
} 
that the government is determined to raise the status of indigenous languages, thereby reinforcing the multilingual status of the country and giving credence to multilingualism, though Simo Bobda (2001) cited in Ngefac (2011) provides a picture of discontentment which he says has characterized some Anglophones in Cameroon. Simo (ibid) holds that Anglophones have often complained against "accumulated injustice perpetrated against their language, themselves and their culture.... after a quarter of a century of co-existence with their Francophone countrymen".

\section{COUNTRY OVERVIEW}

In 2007 the population of Cameroon was estimated at nineteen million $(19,000,000)$ inhabitants A (2008) with $41 \%$ of the population aged 14 years and under (UNSTATS, 2008). The general population increased by $9 \%$ between 2002 and 2007 . The rural population stood at about 9.7 million in 2005, in comparison to 9.3 million urban population. This gave a percentage of $51 \%$ for the rural population and $49 \%$ urban population (UNDP, 2008). By 2019, the population had grown to about twentyfour million four hundred thousand $(24,400,000)$ with $55.7 \%$ urban and $44.3 \%$ rural (National Institute of Statistics; Cameroon).

In terms of ethnic groups, the categorization drawn from the CIA (2008) Report is based on very large re-groupings. For example, the Highlanders category (31\%) covers both the French-speaking West region and the English-speaking Northwest region. Similarly, the Equatorial Bantu category (19\%) consists of the Southwest region (English-speaking) and the Littoral region (French-speaking). The Ethnologue website (http:/en.wikipedia.org/wiki/Ethnologue) meanwhile suggests that the ten most populous ethnic groups comprise less than one quarter $(25 \%)$ of the country's population. The other $75 \%$ of the population is made up of 265 different ethnic groups. Ethnologue (2005) lists the ten most populous ethnic groups in Cameroon as follows: Beti $12.26 \%$ (made up of Fang, Ewondo, Bulu and Mangisa); Fulfulde 4.10\%; Ghomala 1.60\%; Bassa 1.41\%; Bamoun 1.31\%; Medumba 1.28\%; Tupuri 0.077\%; Fe'fe 0.76\%; Akoosé $0.61 \%$ and Duala 0.54\%. These statistics show that there is no dominant indigenous language in the Republic of Cameroon.

Though some languages were taught in some parts of the country (for instance Duala in the Littoral and Southwest Province, Mungaka in the Northwest Province $)^{5}$, the former colonizers and the new Cameroon government, at independence did not think it prudent to adopt any of them for official purposes. It was thought that the indigenous languages could not be easily adapted to technology or be used at the diplomatic level at the time of independence. For these reasons, the government thought the best option was to adopt English and French as official languages at the wake of independence which opened the way for bilateral and multilateral relation-

\footnotetext{
${ }^{5}$ Before the constitutional amendment of 1984, Cameroon was made up of ten administrative units called Provinces. This appellation changed to Regions with the putting in place of the 1984 revised Constitution.
} 
ships, although the example of a country like South Africa could have been emulated. South Africa has eleven languages used officially alongside two European languages - English and Afrikaans - plus one other South African home language of a particular region. This is equally the case with some East African (Kenya and Tanzania), Central Africa (Congo), and West Africa (Senegal) countries where either English or French was adopted as official language alongside Swahili or Kiswahili in Kenya and Tanzania, Lingala in Congo or Wolof in Senegal.

\section{METHODOLOGY}

For the present study, interviews were conducted with thirty participants of both sex and both linguistic backgrounds. The intention was to collect relevant data on the benefits (if any) that have accrued from the adoption of English and French as official languages and to find out if the multicultural nature of the country was of any advantage to Cameroonians. Of the thirty participants in the study, twenty were Francophone and ten Anglophone. The 20:10 ratio is a reflection of the population ratio in the country (75\% Francophone and 25\% Anglophone). The participants' responses are quantified and analyzed following the cultural-linguistic factors in the study. What is important is not the number but the quality of the participants. They were chosen on the basis of their profiles and their level of education as well as on their knowledge of the Cameroonian landscape.

\begin{tabular}{|c|c|c|c|}
\hline Profile & $\begin{array}{l}\text { Franco- } \\
\text { phones }\end{array}$ & $\begin{array}{l}\text { Anglo- } \\
\text { phones }\end{array}$ & $\begin{array}{c}\text { Total } \\
\text { number }\end{array}$ \\
\hline University lecturers (Sociolinguists) & 05 & 03 & 08 \\
\hline Legal practitioners & 01 & 01 & 02 \\
\hline Forestry engineers & 02 & 01 & 03 \\
\hline Human Rights advocates & 02 & 01 & 03 \\
\hline Civil administrators & 03 & 01 & 04 \\
\hline $\begin{array}{l}\text { Pedagogic inspectors in charge of } \\
\text { bilingualism }\end{array}$ & 04 & 02 & 06 \\
\hline Postgraduate students & 03 & 01 & 04 \\
\hline Total & 20 & 10 & 30 \\
\hline
\end{tabular}

\section{ANALYSIS}

Cameroon's official bi-linguistic and bicultural policies and its unofficial multilingual and multicultural nature have opened the country's doors to developmental factors from different dimensions. Table 1 above shows the number and quality of the interviewees who participated in the study. The various respondents gave reasons why they think the country's cultural/linguistic nature is to the advantage of the citizens. Ten of them talked of the country's adherence to important world linguistic organi- 
zations - Commonwealth of Nations and the Organization of the Francophonie - as an advantage to Cameroon and to Cameroonians. Five respondents, all civil servants, gave their views on how both official languages are used within the public service. The university lecturers and postgraduate students looked at the situation from an academic point of view. A lecturer held that the creation of the National Commission for the promotion of bilingualism and multiculturalism was a giant step in resolving problems based on linguistic differences. Generally, these respondents think that much still has to be done, especially in the acquisition of both official languages by youths who will take over the administration of the country. Both legal practitioners interviewed talked of the harmonization of the Cameroon Criminal Procedure Code as a positive measure taken by government. They think this was possible thanks to the official bilingual nature of the country. Ten participants think that home languages have to be encouraged because the languages are more part of the country's identity than the received languages. Some respondents gave their view on the way forward.

\subsection{MEMBERSHIP INTO INTERNATIONAL LINGUISTIC ORGANIZATIONS}

Cameroon's official bilingual status has enabled the country to become a member of a number of respected world organizations within which very important decisions on developmental issues are discussed and bilateral and multilateral relations strengthened. Two of such very important organizations are the International Organization of the Francophonie and the Commonwealth of Nations.

\subsubsection{MEMBERSHIP INTO THE INTERNATIONAL ORGANIZATION OF THE FRANCOPHONIE}

Cameroon joined the French Agency for Cultural and Technical Cooperation (ACTC) in 1975 and gained observer status into the International Organization of the Francophonie during its 4th summit of Heads of State and Government held in Chaillot, France. A lecturer in the Department of French language of the University of Yaounde 1, in his interview states the following:

Cameroon has a multi-form relationship with the International Organization of the Francophonie in the political, economic, cultural, and technical domains. The country plays a major role within the organization, notably in the adoption of a new charter, the conception of new political and economic objectives, as well as the putting in place of new institutions like the General Secretariat which is in charge of political actions at the international level.

Such changes integrate the need for political powers to exercise democracy and the promotion of legally constituted states. These political exigencies formulated by the Francophonie, were echoed in Cameroon, where the government took steps to redeploy institutions and administration of public liberties. 
According to Ousman Paye, special adviser to the Secretary General of the Organization, Cameroon and the Francophonie have a satisfactory relationship. He avers that Cameroon is an eminent member of the Francophonie. The country is a good example as concerns both its statutory and voluntary contributions. It is rare for a country of the south hemisphere to voluntarily contribute to the Organization. Cameroonians are omnipresent in the major machinery of the Francophonie and they participate in the elaboration of major texts which will be on the table during the Quebec summit.

One of the pedagogic inspectors thinks that the admission of Cameroon into the Commonwealth of Nations and the International Organization of the Francophonie, with English and French languages as emblems of identification respectively, relaunched the country's attachment to both languages and cultures. Many Cameroonian parents saw in these memberships a means for their siblings to obtain scholarships and international opportunities offered by both the Commonwealth of Nations and the International Organization of the Francophonie as well as English-speaking and French-speaking industrial countries.

Anchimbe and A (2011) writes that after Cameroon's adherence to the International Organization of the Francophonie, many Cameroonians saw benefits for the country to adhere to the Commonwealth of Nations. Anchimbe (ibid) equally holds that due to these factors, the place of both English and French, especially that of the English language, and their range of functions were encouraged. An example is the Prime Ministerial circular published in Cameroon Tribune $\mathrm{N}^{\circ} 4951$ of 03/08/1999, p. 3, which outlined 'The steps to take in order to project an image of a bilingual Cameroon'. One of the civil administrators averred that:

The International Organization of the Francophonie has financed projects related to cinematography and audiovisual in Cameroon. The Organization has equally helped in the development of the cultural industry and the transportation of Cameroonian artists to international events. On the social plan, the Organization helps vulnerable groups (women and children) and local communities through the Special Program for Development in financing water projects, food security, the valorization resources and local production and capacity building.

\subsubsection{MEMBERSHIP INTO THE COMMONWEALTH OF NATIONS}

Cameroon joined the Commonwealth of Nations in November 1995, thirty-five years after its independence in 1960. The country became the first Francophonie nation to become a Commonwealth member. Participants in this study all agree that the official bi-linguistic and bicultural status of the country played in its favour and enabled the country to adhere to what is commonly known as the 'Gentlemen's club'. One of the participants (a lecturer) pointed out thus, during the tenor of the country's first president, the government was lukewarm to the idea of joining either the Commonwealth of Nations or the International Organization of the Francophonie. The arrival of a new president in 1982 ushered in an era of democratic reforms aimed at greater 
decentralization, coinciding with pressure from the Anglophone minority for Commonwealth membership.

An application for observer status was granted in 1989. Since its successful application for full membership in 1995, the country has become involved in a range of Commonwealth activities, and stands to benefit from Commonwealth assistance in overcoming some of its social and economic problems.

In 2003, two meetings of the Commonwealth Commission were held to assess and discuss progress on the Cameroon reform agenda. The discussion focused on electoral management, judiciary and prison systems, human rights, and decentralization. The Commission presented proposals for funding to international bilateral and multilateral partners in support of the implementation of reforms in Cameroon. In 2005, the Commonwealth of Nation made a commitment to assist in establishing an independent electoral management body in Cameroon.

One of the respondents (a Human Rights advocate) pointed out that:

The elections held in Cameroon on $22^{\text {nd }}$ July 2007 were observed by a Commonwealth Observer group. The team was tasked to assess the conduct of the elections and the general environment for the polls. The team assessed the conduct of the National Election Observatory (NEO) and plans for the establishment of a new election commission (ELECAM) ${ }^{6}$. The team's report identified a strategy for Commonwealth engagement with Cameroon on the future establishment and capacity building of ELECAM, as well as other necessary electoral reforms.

The Cameroonian media has equally benefitted from financial and material assistance from the Commonwealth of Nations, which has also offered training programs on good governance to journalists in Cameroon.

\subsection{THE STATE MACHINERY}

The representation of Cameroon as an official bilingual and bicultural country is not a new concept in Cameroon politics; it can be traced back to the time of European occupation. From 1918 to 1960 both the English and the French imposed their languages on the different administrations in the section each governed. After independence in 1960 and reunification in 1961, there was continuity in the use of the European languages and the systems of administrations in Cameroon.

One of the issues in language in Cameroon is that, it focuses not on the basic principles of state bilingualism, but on its ability to actually achieve its end. In the context of the public administration, for instance, the evidence is the creation of pilot linguistic centers by the Presidency of the Republic. These centers aim at enabling adult learners, who missed the opportunity to become bilingual at youth, to acquire their second official language, that is, English for Francophones and French for Anglophones. Pilot linguistic centers are today found in eight of the ten administrative regions in Cameroon: Bafoussam (West Region), Bamenda (Northwest Region), Bertoua (East Region), Buea (Southwest Region), Douala (Littoral Region), Ebolowa (East Region),

\footnotetext{
${ }^{6}$ ELECAM (elections Cameroon) replaced NEO in 2010
} 
Ngaoundere (Adamawa Region), and Yaounde (Center Region).

A number of government texts reinforce Article 1 paragraph 3 of the Constitution which states, "The official languages of the country shall be English and French, both having the same status". The paragraph further states that, "The State shall guarantee the promotion of bilingualism throughout the country". Prime Ministerial Circular Letter $\mathrm{N}^{\circ} 001 / \mathrm{CAB} / \mathrm{PM}$ of $16^{\text {th }}$ August 1991 and Circular Letter $\mathrm{N}^{\circ} 685 / \mathrm{CAB} / \mathrm{PM}$ of $25^{\text {th }}$ April 2000 both put emphasis on the practice of bilingualism in the public service and state corporations.

Government measures towards promoting bilingualism have continued. Ayafor (2005) writes that in 1999 the Language Service and Bilingualism Division at the Presidency of the Republic, which is charged with government's language management programs, created a sub-section called 'The Guidance, Harmonization, and New Technologies Section'. The section has since May 1999 published a quarterly 'Terminology Bulletin' which henceforth publishes official terminology; a kind of language regulatory guide which may as well fit into language planning measures. In the first publication, the then Secretary General at the presidency of the Republic states the following:

The Secretariat General of the Presidency of the Republic is pleased to launch this maiden issue of 'Terminology Bulletin'. This initiative falls in line with the new orientation given to the Guidance, Harmonization and New Technologies Section.... namely, harmonization and dissemination of official terminology; the guidance of translators in government and other services, and the quality of translations through standardized terminology. This Bulletin is intended to be an indispensable working tool, among others, for professionals of inter-lingual communication, especially within official circles. Translators, Interpreters, Journalists, communication experts, executive and the public at large are encouraged to use official terminology so as to communicate efficiently and without ambiguity in their daily activities within the meanders of the administration ...In this maiden issue we publish the official appellation of government Ministries and some important Services attached to the Presidency of the Republic. In so doing, we want to avoid the use of unofficial renderings for these all-too-important state structures and services as has been the case for a long time.

Such language measure and others taken at the levels of the Prime Minister's Office and other ministerial departments have helped to forge ahead the policy of bilingualism within the administrative machinery.

A respondent - a pedagogic inspector - in the Ministry of Secondary Education argues that the official bilingual/bicultural status contributes to the development of the economy of the country. It has enabled, for instance, the implantation of some major Chinese and other Asian companies in Cameroon which recruit mostly bilingual Cameroonians as interpreters and field workers. Cameroon is benefitting from its bilateral cooperation with the Peoples' Republic of China in the realization of major projects aimed at enabling the country towards its 2035 emerging goal. 
In line with the economic benefits of a bilingual system, Richard Riley, US Secretary for education argues that:

In an international economy, knowledge of a second language is power. Those who speak English as well as another language will be wonderful assets for our nation in the coming years, so, I am encouraging our schools to adopt an 'English plus one' approach. This challenges young people to meet high academic standards in two languages (2000).

In the content of public service hiring, the government adopted a strategy of increasing the number of bilingual personnel. There are two key reasons for this initiative: 1) to ensure that Cameroonians are able to receive services in either official language, and 2) to increase the employment opportunities for Cameroonians within the public service.

Prior to the adopting of these measures, English-speaking Cameroonians were at a major disadvantage as French was the primary language of business in the public service, especially in the capital city of Yaounde, where all the main administrative departments are located. English-speaking Cameroonians seeking for state employment had, to a certain extent, to be bilingual and prepared to work almost exclusively in their second official language, especially those who were transferred to Frenchspeaking regions.

As earlier said, language policy at this level focuses not on the basic principle of government bilingual policy but on its ability to actually achieve its ends. In the context of the public service, the participation rates of English-speaking Cameroonians have improved greatly between the 1990s and the present.

Improved participation rates of English-speaking Cameroonians in the public service, however, does not mean that the public service has become more bilingual. Investigation on official bilingualism shows that there is still an imbalance in the use of the two official languages in the public service. French remains the official language of work used by public servants, to the detriment of English, except in the two English-speaking regions of the Southwest and Northwest. The same investigation also found that the offer of service in either language by the public service remains inadequate. This is due, to a large extent, to the inequality in population between Anglophone and Francophone Cameroonians.

In the mass media, two radio language programs were developed and used in the two official languages from 1967: 'Le français par la radio' in the English-speaking provinces, and 'L'anglais chez vous' in the French-speaking regions Chumbou (1980), Mbangwana (1999). Today, the public media - Cameroon Radio and Television Corporation (CRTV) - since 2014 has tried to equate the number of programs in both official languages, especially the news casts. CRTV radio has five major daily prime time news cast in French ( $6 \mathrm{am}, 1 \mathrm{pm}, 5 \mathrm{pm}, 8 \mathrm{pm}$, and $11 \mathrm{pm}$ ) and four in English ( $7 \mathrm{am}, 3 \mathrm{pm}, 7 \mathrm{pm}$, and $10 \mathrm{pm}$ ). In 2019 the major news cast of 5 pm became bilingual with Anglophone and Francophone journalists broadcasting at the same time. 
From Monday through Friday, CRTV television has one major news-cast in English at 7:30 pm and one in French at 8:30 pm. On weekends (Saturdays and Sundays) and during national days ( $11^{\text {th }}$ February and $20^{\text {th }}$ May) the news cast is bilingual at 8:30 pm. The public print media, Cameroon Tribune is equally making efforts to promote the use of both official languages and cultures, even if the French language still dominates. Though these efforts are appreciated, there is still much to be done for Cameroonians of both 'cultural' backgrounds to live together peacefully and in harmony.

\subsection{THE EDUCATION SECTOR}

As in the case of the public service, the bilingual policy has also witnessed a good number of successes in the area of education. Since the creation, by the government, of the first bilingual secondary institution in Man-0-War Bay in 1963 and the second in 1965 in the administrative capital, Yaounde, the tendency has been the continuous creation of such institutions to foster official bilingualism and 'biculturalism'. By 2005 the total number of bilingual secondary schools in the country was 106 (see Alobwede, 2007). Today, almost all public single-language secondary institutions have been given a bilingual status.

On $29^{\text {th }}$ June 2012, a decision of the Minister of Secondary Education created the 'Bepc bil'7. This was a special education programme (SEP). The examination was to be taken for the first time during the 2012/2013 academic year in Cameroon. According to the ministerial decision, the examination is meant for students who attain the level of 'Troisième Bilingue', that is, bilingual Form Four at the secondary level. Within the framework of the implementation of SEP, a number of both state and private schools were selected as pilot schools. These pilot schools were selected during the 2009/2010 academic year for the classes of 6e and Form 1, considered as bilingual '1er Année' or First Year bilingual. Sixty candidates were selected during the first year after the administration of a special language test. These pioneer students were in '3e bilingue' (bilingual form four) during the 2012/2013 academic year and during which year they sat for the final examination. The first students of the program were in Form Five during the 2013/2014 academic year and sat for the first 'GCE Ordinary Level Bil'.

Interviewed on the pertinence of such an academic program, Mr. John SuhNjibanum, pedagogic inspector in charge of the promotion of bilingualism in the Ministry of Secondary Education holds that:

L'idée est de produire de jeunes Camerounais parfaitement bilingues. Et pour y arriver, nous savons que l'idéal est de passer par les établissements secondaires, notamment par des programmes effectivement bilingues. Ce programme d'éducation bilingue fait la différence parce qu'il n'y aura plus de francophones ni d'anglophones, mais des Camerounais qui s'expriment parfaitement dans les

\footnotetext{
${ }^{7}$ Brevet d'étude du premier cycle bilingue: Bilingual examination at the end of the first cycle of secondary education.
} 
deux langues officielles du pays. Maintenant, dans les établissements pilotes, nous produisons quand même 2500 Camerounais bilingues.

(The idea here is to produce perfect young Cameroonians. The ideal place to attain such goal is the secondary school, especially with a good bilingual program. This new program is different because there will be neither Francophones nor Anglophones, but simply Cameroonians who are able to perfectly express themselves on both official languages. Presently we have about 2500 bilingual Cameroonians from the pilot schools).

The enrolment of children of French-speaking background into either Englishspeaking or bilingual schools, has increased enormously. Anchimbe and A (2011) reports the percentage of francophone children in English-medium schools, not only in metropolitan cities like Yaounde and Douala, but also in predominantly Englishspeaking cities like Bamenda, Bafut and Mankon in the Northwest Region of the country. Two surveys were carried out in 2003 on nursery and primary schools and in 2006 on secondary schools which show the high rates of enrolment of children from French-speaking families into English-medium schools. This tendency has not changed till present date.

Table 2 Enrolment into English-medium nursery, primary and secondary school (2003 and 2006)

\begin{tabular}{|c|c|c|c|c|c|}
\hline Institution & $\begin{array}{c}\text { Total } \\
\text { enrolment }\end{array}$ & Anglophones & $\%$ & Francophones & $\%$ \\
\hline $\begin{array}{c}\text { Franky Nursery \& } \\
\text { Primary School - } \\
\text { Yaounde }\end{array}$ & 447 & 201 & 45 & 246 & 55 \\
\hline $\begin{array}{l}\text { Jumping Jacks } \\
\text { Nursery \& Primary } \\
\text { School - Yaounde }\end{array}$ & 485 & 145 & 30 & 340 & 70 \\
\hline $\begin{array}{c}\text { Holy Infants School - } \\
\text { Yaounde }\end{array}$ & 850 & 457 & 53.5 & 393 & 46.7 \\
\hline $\begin{array}{l}\text { Presbyterian Girls } \\
\text { Secondary School - } \\
\text { Limbe (Form 1) }\end{array}$ & 160 & 130 & 81.5 & 30 & 18.5 \\
\hline $\begin{array}{c}\text { Presbyterian } \\
\text { Secondary School - } \\
\text { Bafut (Form 1) }\end{array}$ & 160 & 120 & 75 & 40 & 25 \\
\hline $\begin{array}{l}\text { Baptist Secondary } \\
\text { School - Mankon } \\
\text { (Form 1) }\end{array}$ & 150 & 129 & 86 & 21 & 14 \\
\hline $\begin{array}{l}\text { Our Ladies of Lourdes } \\
\text { Secondary School - } \\
\text { Mankon (Form 1) }\end{array}$ & 140 & 100 & 71.5 & 40 & 18.5 \\
\hline $\begin{array}{l}\text { Sacred Heart College - } \\
\text { Mankon (Form 1) }\end{array}$ & 140 & 122 & 87 & 18 & 13 \\
\hline
\end{tabular}

Source - Anchimbe, 2011

With the advent of the Anglophone crisis in late 2016 and the interruption of classes in the two Anglophone Regions, more private Anglo-Saxon secondary institu- 
tions have been set up in Francophone Regions, which has given more Francophone children the opportunity to have English-oriented education.

At the tertiary level, there are eight state universities in the country, six of which are bilingual in nature where lectures are in both English and French. These are the universities of Yaounde1 created in 1962, the University of Yaounde II created in 1993, the University of Buea created in 1993, the University of Douala created in 1993, the University of Dschang created in 1993, the University of Ngaoundere created in 1993, the University of Maroua created in 2008, and the University of Bamenda created in 2010. Of the eight universities, only the University of Buea is purely Anglo-Saxon and that of Ngaoundere, French oriented.

One of the interviewees pointed out that benefits within the education sector include scholarship obtained from both the Commonwealth and the Francophonie. Each year, the British Government makes around 500 awards to applicants from Commonwealth countries including Cameroon as its contribution to the Commonwealth Scholarships and Fellowships plan. These awards cover doctoral studies, master's degrees and academic or short-term professional fellowships. There are also opportunities for distance learning courses and split-site schemes in which part of a doctoral degree is carried out in the United Kingdom. These awards are made strictly on academic merit.

For Cameroonians, literacy in both languages is important in order to develop a deep understanding of their languages and cultures. Bilingualism equally plays an important role in giving Cameroonians, mostly students, choices in developing their cultural identity and academic options. A lecturer and parent in Yaounde, who was interviewed on the status of official bilingualism, had this to say:

As a parent, like all parents, I want more than anything that my children are happy and healthy. And as my children have backgrounds in two cultures, I believe that the extent to which they feel able to claim any or both cultures as their own is important to their happiness, and even perhaps to their health. The extent to which bicultural children are able to feel a sense of belonging to any of their cultures is, research as shown, related to being able to use the language of that culture. And being able to speak a language is, as research has also shown, enhanced by being able to read and write the language. So, as a parent of bicultural children, it behooves me to support my children in developing their reading and writing skills in both English and French as fully as possible in order that they have a range of options open to them.

Some post-colonial studies in Cameroon show that French-speaking Cameroonians are today passionately opting for English and its education system Anchimbe and A (2011), unlike in the 70s, 80s, and 90s when some Francophones perceived English as a language of $2^{\text {nd }}$ class citizens or the language of the oppressed, with expressions as 'anglo', 'gauch', or 'anglofou'. This enthusiasm towards learning English is a visible proof that Cameroonians are more and more embracing bilingualism and 'biculturalism' and the advantages that accrue from them. 
Richard W. Riley (2000), on the importance of bilingualism and biculturalism, says:

It is high time we begin to treat language skills as the asset they are, particularly in this global economy. Anything that encourages a person to know more than one language is positive - and should be treated as such. Perhaps we should begin to call the learning of a second language what it truly is - 'bi-literacy'. Today, I want to spotlight the dual language approach which is also sometimes referred to as twoway bilingual or dual immersion education. I am challenging our nation to increase the number of dual-language schools to at least 1,000 over the next five years, and with strong federal, state and local support, we can have many more. Right now, we have about 260 dual-immersion schools and that is only a start. We need to invest in these kinds of programs and make sure they are in communities that can most benefit from them. In an international economy, knowledge - and knowledge of language - is power. Our nation can grow stronger if all our children grow up learning two languages... I can assure you that when they enter the workforce in several years, we will regret the inability of our children to speak two languages. Our global economy demands it; our children deserve it.

Baker (2000) avers that research between 1920 and 1960 showed that bilingualism was regarded by some researchers as being intellectually and psychologically detrimental to the individual. However, this research was later found to be flawed (Hakuta, 1990). Research since 1969 indicates that rather than having a negative connection, there is actually a positive link between bilingualism and cognitive ability (Baker, 2000; Bialystok, 2001), particularly when children are able to speak both languages at the age of ten (Bialystok, 2001; Cummins, 1987). According to Hakuta (1990), "Bilingualism can lead to superior performance on a variety of intellectual skills", and research has shown bilingualism to be associated with development of abilities in concept formation, creativity, and analogical reasoning (Pennington, 1996a)), as well as meta-linguistic skills (Bialystok, 2002). Robertson (2004) has categorized possible advantages for the bilingual person as being: linguistic, socio-cultural and procedural in nature. In a review of research on bilingualism and brain development, Forman (2000) describes a bilingual as being better able to abstract information, ignore misleading information, filter out distraction and switch back and forth between tasks. There has also been evidence of a positive relationship between reasoning abilities, including nonverbal problem-solving skill, divergent thinking skills, field independence and bilingualism (Cummins, 1987).

\subsection{HARMONIZATION OF THE CAMEROON LEGAL SYSTEM}

At independence, the French-speaking section of the country adopted the French legal system, that is, the civil law judicial system, while the English-speaking section adopted the Common law legal system. The existence of two legal systems within the same country generated an element of 'discrimination'. Most, if not all, Anglophone 
magistrates who graduated from $\mathrm{ENAM}^{8}$ were posted to work in either the Southwest or the Northwest Regions of the country, two regions where the Common Law legal system is used. This was same for Francophone magistrates who were, in majority, posted to the other eight regions of the country. In order to continue to foster official bilingualism, the government in 2005, decided to harmonize the Criminal Procedure Code. One of the legal practitioners interviewed for this study observed that the Code was harmonized, amended and put into force by law $\mathrm{N}^{\circ} 2005 / 007$ of $27^{\text {th }}$ July 2005. It lays down the principles and procedures involved in criminal actions and stipulates the rules which deal particularly with the investigation of offenses, the search and identification of offenders, the method of adducing evidence, the powers of those charged with prosecution, the organization, composition and jurisdiction of courts in criminal matters, verdict, sentencing, the right of the parties and the methods of executing sentences. As a matter of fact, the new Code is better defined and structured.

With the advent of the new Code and the present state of affairs in the country, one can say that Cameroon is witnessing a positive change in its judicial system. The basic human rights of citizens are guaranteed in the Code. For instance, the presumption of innocence in any legal suit which is of prime importance to the suspect is well defined. Unlike the old Code which stipulated that guilt must be proven beyond reasonable doubts, the new Code holds that any person suspected of having committed an offence shall be presumed innocent until their guilt has been legally established in the course of a trial where they shall be given all necessary guarantees for their defense. This in effect, means that guilt must be proven at all cost. There must be no doubt in establishing guilt. The least doubt disqualifies guilt. The presumption of innocence shall also apply to every suspect, defendant or accused.

Tande Dibussi (2007) in an article titled, 'Can Cameroon's New Criminal Procedure Code deliver justice with a human face?' opines that, "The Code is a hybrid system which merges key features of the French Civil law and the English Common Law system, along with customary law. The Code is a landmark legislation which seeks to promote what has been described as 'Justice with a human face"'.

The harmonization of the legal system was another great step taken by government in the promotion of the official bilingual/bicultural nature of the Cameroonian society.

\section{RECOMMENDATION}

In the light of what precedes, it is certain that a number of measures have been taken by government since independence and reunification to improve on the status of official bilingualism and biculturalism in Cameroon. Giving that societies evolve and development is a continuous process, there is need for the state to continue improving on its linguistic status. New approaches to cultural/linguistic problems have to be adopted. A number of countries had earlier embarked on reformatory programs

\footnotetext{
${ }^{8}$ French acronym which stands for 'Advanced School of Administration and Magistracy'
} 
in the domain of bilingualism and biculturalism.

In the United States, for instance, the States of Massachusetts, Texas and Illinois adopted laws on bilingualism/biculturalism programs in 1971 and 1973 respectively. These laws, which were voted in the different Houses of Representatives, authorized the different States to launch mandated bilingual programs which required instructions in both the English language and the native language and culture of the children, to equalize their educational opportunities.

Canada is a very good example to emulate in the domain of official bilingualis$\mathrm{m} /$ biculturalism. The Canadian Government, on September $19^{\text {th }} 1969$ adopted The Official Language Art which was amended in 1988. The Art is considered as the legislative keystone of Canada's official language policy. The Canadian government has set in place regulations establishing linguistic categories (Anglophone, francophone, bilingual) for some job functions within the public service. Departments and agencies of the federal government are required to fill these positions with individuals who are capable of serving the public in English, in French, or in both languages. Unilingual public servants are given incentives to learn the other official language, and government provides language training and offers 'bilingualism bonuses.

In relation to the use of home languages, the examples of countries like Senegal, Nigeria, South Africa, Kenya, and Tanzania abound. These countries were able to adopt linguistic policies within which received languages are used alongside some home languages as official languages. The creation of a department of home languages in the Yaounde Higher Teacher Training College (ENS) is welcomed. The government should open similar departments in all state universities. The teaching of home languages and cultural values should equally be extended to basic and secondary education as it is the case in a country like Nigeria where Ibo, Yoruba and Hausa are taught from the primary level side by side with the English language.

After more than half a century of preaching integrative motivation for Cameroonians to be bilingual, the government should adopt a law on instrumental motivation to encourage denizens to become bilingual. Like it was the case in Canada in the 1970s, Cameroonian's state employees who are bilingual in both official languages should be given certain incentives that monolinguals will not receive; for instance, in appointments to positions of responsibility within the state machinery. For this, government will have to define the degree of bilingualism to be attained for one to be considered eligible for such incentives.

\section{CONCLUSION}

In the light of the complexity and ambiguity surrounding bilingualism and biculturalism in Cameroon, perhaps the best thing to do is to help official bicultural persons develop their language ability as fully as possible. As Murphy-Shigematsu (1997) has observed, "Language is the most basic cultural skill that enables a person to say with confidence that they belong to a group". Doing this is not necessarily a straightfor- 
ward process.

The official bilingual policy in Cameroon has been criticized by some Cameroonian linguists who think that the exclusive language management strategy in the country may not be viewed as a linguistic policy in the real sense of the term. These linguists think that the strategy lacks basic clear-cut linguistic definition and description (Chumbow, 1980:288) and a systematic framework for its implementation (Tadadjeu, 1983:117). It may be up to everyone (or community) to choose the definition of bilingualism that best suits the purpose. The government in Cameroon insists on the fact that what is being practiced in the country, that is, the creation of bilingual schools and pilot linguistic centers is a policy of bilingualism, although Ayafor (2005) puts a question mark on such a stand by asking the extent to which bilingualism may be arbitrary and remain acceptable as a language policy or to what extent should language maintenance be considered a good index of consistent planning? Should it be represented in terms of a continuum? If the policies were considered as they are, at what point may they become (successful) language policies?

This paper has examined the official bilingual/bicultural policy in Cameroon from socio-political, historical, and cultural perspectives during the period of independence from 1960 to present date. It is obvious that the current sociolinguistic situation is a continuation of the linguistic policy of the period before independence. The contribution of this paper lies in the fact that it has approached the official bilingualism policy in Cameroon from a developmental angle different from that of most Cameroonian linguists who see the official bilingual policy as a failure because of the lack of a well-defined language policy. The paper has shown that, although the language policy, as practiced by the government, may not be the best from a sociolinguistic perspective, it has nevertheless helped the country to advance in many directions. Official bilingualism and biculturalism have equally opened the gateway for bilateral and multilateral relationships with international organizations, which is a booster to the country's developmental initiatives.

Alobwede (2011); Bialystok (2000); Cummins (1976); de Boschère et al. (1961); Echu (2003); Hakuta (1990); "Inaugural Statement At The Bilingual Grammar School" (1965); Mforteh (2006); Minesec (2010); Murphy-Shigematsu (1997); Tadadjeu (1983); Trudgill (1992)

\section{REFERENCES}

A, C. I. (2008). Report On Cameroon. Report On Cameroon. Retrieved from Https://Www.Cia Gov/Library/Publications/The-World-Facebook/Geos/Cm.Html

Alobwede, E. C. (2011). Bilingual Education In Cameroon: An Appraisal Of The English SubSystem At The Secondary Level. Revue Internationale Des Arts. Lettres Et Sciences Humaines (Rialsh), 1.

Anchimbe, E., \& A. (2011). Socio-Historical Landmarks In Francophone Cameroonians' Resistance To English. Revue Internationale Des Arts, Lettres Et Sciences Humaines (Rialsh), 
1.

Anjali, P. (2007). Hybridity: Limits, Transformation, Perspectives. Hybridity: Limits, Transformation, Perspectives, 791470423-791470423.

Ayafor, I. M. (2005). Official Bilingualism In Cameroon: Instrumental Or Integrative Policy? Proceedings Of The 4th International Symposium On Bilingualism.

Bialystok. (2000). Bilingualism In Development . Cambridge University Press.

Chumbou, B. S. (1980). Language And Language Policy In Cameroon. In K. Kale \& N. (Eds.), An Experiment In Nation-Building: The Bilingual Cameroon Republic Since Reunification (pp. 281-311). Boulder, Co: Westview Press.

Cummins. (1976). A Synthesis Of Research Findings And Explanatory Hypothesis. The Influence Of Bilingualism On Cognitive Growth: A Synthesis OfResearch Findings And Explanatory Hypothesis. Working Papers On Bilingualism. Ontario Institute For Studies In Education.

de Boschère, G., Compton, A., Dieng, A. A., Diop, A., Irele, A., Laude, A., \& Thembani, D. (1961). Palabre. Présence Africaine, XXXVI, 137-137. Retrieved from https://dx.doi .org/10.3917/presa.036.0137 10.3917/presa.036.0137

Echu, G. (2003). Coping With Multilingualism: Trends In The Evolution Of Language Policy In Cameroon. Phin, 25, 31-46.

Ejedepang-Koge. (1985). Change In Cameroon. Change In Cameroon. Retrieved from Https:// Www.Google.Cm/Search?Tbm=Bks\&Hl=Fr\&G=Ejedepang\%2c+1987

Ethnologue. (2005). Languages Of The World Archived 15th Edition. Languages Of The World Archived 15th Edition. Retrieved from Https://Www.Goodreads.Com/Book/...1040795 Ethnologue

Gordon, \& Raymond. (2005). Journey With Jesus. Journey With Jesus”. Ethnologue: Languages of The World Archived 15th Edition. Retrieved from Https://Www.Goodreads.Com/ Book/...1040795.Ethnologue

Hakuta. (1990). Language And Cognition In Bilingual Children. “Language And Cognition In Bilingual Children, 20-20.

Inaugural Statement At The Bilingual Grammar School. (1965). Inaugural Statement At The Bilingual Grammar School". Yaounde: Archives Of The Presidency Of The Republic Of Cameroon.

Mbangwana, P. N. (1999). Linguistic Deculturation Of English Usage In Cameroon. In Echu \& Grundstrom (Eds.), Linguistic Deculturation Of English Usage In Cameroon (pp. 87102).

Mbassa, M. (1976). The State Of Contemporary English In Cameroon. Cameroon Studies In English And French (Casef).

Mforteh, S. (2006). Cultural Innovation In Cameroon's Tower Of Babel. Cultural Innovation In Cameroon's Tower Of Babel. Trans 16. Retrieved from Https://Www.Inst.At/Trans / 16nr/03_2/Mforteh16.Htm

Minesec. (2010). Programmes Officiels De L'enseignement Bilingue (Bepc/Gce Bilingue). In Programmes Officiels De L'enseignement Bilingue (Bepc/Gce Bilingue). Yaoundé, Sopecam.

Murphy-Shigematsu. (1997). Culture And Psyche. Culture And Psyche. Retrieved from Https://Www.Murphyshigematsu.Com/.../American-Japanese

Ngefac, A. (2011). Linguistic Choices In Postcolonial Multilingual Cameroon. In Revue Internationale Des Arts, Lettres Et Sciences Humaines (Rialss) (Vol. 1). African Publication.

Tadadjeu, M. (1983). Prospects For Language Planning Studies In Cameroon. In Prospects For Language Planning Studies In Cameroon" In A Sociolinguistic Profile Of Urban Centres In 
Cameroon. California: Crossroads Press.

Trudgill, P. (1992). Introducing Language and Society. In Introducing Language and Society. London, Penguin. 